https://doi.org/10.48009/1_iis_2008_613-621

\title{
THE RELATIONSHIP OF E-COMMERCE READINESS TO TECHNOLOGY ACCEPTANCE: THE CASE OF BARBADOS
}

\author{
Jude E Edwards, Spicer Memorial College, Pune, India judeedwards@comcast.net \\ Leila A. Halawi, American University of Dubai, drhalawi@gmail.com \\ Richard McCarthy, Quinnipiac University, Richard.mccarthy@quinnipiac.edu
}

\begin{abstract}
This is an exploratory study that examines the relationship between selected components of $e$ commerce readiness and dimensions of Davis' (1989) Technology Acceptance Model. Building upon the notion that there exists some linkage between ecommerce readiness and Technology Acceptance, this study seeks to examine these linkages in e-businesses within Barbados. Three relationships are proposed $-a$ relationship between technology acceptance and the existing e-Readiness infrastructure, a relationship between technology acceptance and current telecommunications access, and a relationship between technology acceptance and education. The results of this study demonstrated that there are strong relationships between e-commerce readiness components and various technology acceptance dimensions.
\end{abstract}

Keywords: technology acceptance model (TAM), ecommerce readiness, Barbados.

\section{INTRODUCTION}

The islands of the Caribbean have long been treated primarily as a bastion for relaxation and seasonal tourism, and for the availability of beautiful beachfront properties [6]. This is due to the fact that many of these islands have limited natural resources and are sandwiched between two major economic regions, - North and South America. Nurse and Punnet [28] suggest that there is an unrecognized, under researched, but pervasive set of antecedent influences that have contributed to the relative absence of technology diffusion or acceptance on many of these islands. Beyond light industries located in large industrial parks, technology has not penetrated into other areas, particularly remote areas. Thus, these islands of the Caribbean have not realized or experienced a greater economic and industrial potential.

The relationship between e-commerce readiness and technology acceptance is an area in international business that benefits from interdisciplinary research, and in which replication and validation studies are extremely beneficial. Few studies have examined how the host country's environment may modify acceptance or adoption of new technology or ideas that are being introduced. Recent studies, focusing on the Caribbean region have recognized that a number of host country environmental elements can have an effect on the rates at which changes occur in the host country [28]. For example, in the area of international management, Nurse and Punnet [40] posit that antecedents such as slavery and past economic systems have had a moderating effect on Caribbean management and economic development. The practical implications of investigations in this area are vast and require additional exploration. However, the body of literature that currently exists in this area is relatively small. This is a domain that has yet to be adequately examined in academic research.

The research problem investigated in this study involved the determination of the level of technology acceptance and e-readiness in Barbados. Three relationships were proposed: a) technology acceptance with existing eReadiness infrastructure, b) technology acceptance with current telecommunication access, and c) technology acceptance with national education. This research had several goals and purposes: (1) To expand research relative to technology acceptance from an academic perspective; (2) To examine the linkage between technology acceptance and e-commerce readiness so that the influence of a technical infrastructure on new technology acceptance may be better understood; (3) To examine the viability of Barbados' becoming a regional telecommunication hub which will affect the economic and industrial development in the entire region. (4) TAM has not previously been applied in the Caribbean, and it may be useful to examine TAM in connection with selected e-commerce readiness components acting as external modifying variables; and (5) To examine linkage between technology acceptance, attitudes and human resource strategies, so that international managers can develop more effective human resource policies, that improve overseas operations. This study is relevant to the business and policy-making community in Barbados. As these policy-makers become highly interested in the results of this study, they may be motivated to introduce policies and practical solutions that will encourage widespread e-commerce implementation and technology acceptance in Barbados. Also, this study adds to that body of literature and to the body of knowledge that will ultimately complete the linkage between the influence of e-readiness and technology acceptance or adoption. The paper is structured as follows: (1) Following this 
introduction is the conceptual framework for this. (2) Next, details associated with the specifics of the research methodology and experimental design is presented. (3) The data analysis approaches are then explained. (4) Finally, the implications of the results and conclusions are presented.

\section{CONCEPTUAL FRAMEWORK}

The conceptual framework used to investigate this problem was the Technology Acceptance Model [10]. The Technology Acceptance Model (TAM) [9][10] is an adaptation of the Theory of Reasoned Action (TRA) [3][4]. According to Davis' TAM, positive perception of technology's ease of use, usefulness, and attitudes towards technology usage are important determinants of the intention to use a technology. This may be called "behavioral intention" [11][12][1][35][36][22][32][26].

The original TAM has since been expanded. The version of TAM that is frequently used today is called TAM2 (figure 1), in which a number of external variables are examined. Davis and Venkatesh [13] originally published the results of three experiments using TAM2. Hubona and Kennic [19] and Hubona and Geitz [20] posit that "the role of external variables impacting usage behavior within TAM has not been well explored". Davis [11] specifically urges that additional external variables be applied to future research using TAM. TAM2 has been used to investigate end-user acceptance or adoption of a variety on information technology systems. TAM2 has been employed to explain and predict technology use in a number of different disciplines: (a) Decision Sciences [13]; (b) Management Sciences [39]; (c) Information Technology [19][20]; (d) Information Technology and Management Information Systems; (e) Information Systems [8], [21][22][24][34][40][7][15][23]; (f) Email Application, [17]; Voice Mail [1][34]; (g) Student Laboratory Systems [37]; (h) Nursing Computer Systems [14]; (i) Computer Assisted Instruction (CAI) and other Hypertext Systems [38]; (j) Personal Computing [21]; Website Usage - [18]; (1) Internet [33] is a representation of TAM2.

Figure 1- TAM2 with External Variables

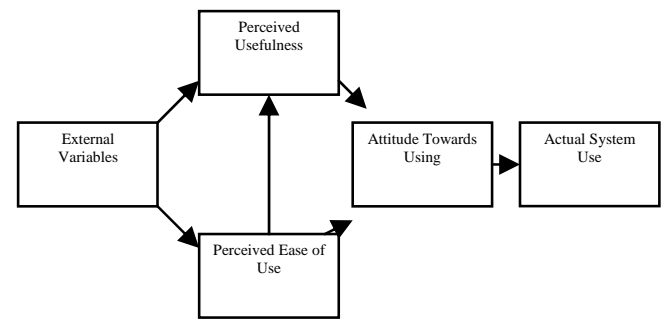

TAM2 has been used to describe and predict technology use in a number of different disciplines such as decision sciences, management sciences, IT and management information systems. TAM2 has been used to assess technology acceptance across several different cultures. TAM2 has also been used to help predict web site usage [16][18].

\section{TECHNOLOGY ACCEPTANCE AND COUNTRY CHARACTERISTICS AND CONSTRAINTS}

Research conducted on technology acceptance from home to host country has focused narrowly on a single element in the host country that acts as either a driver or a constraint. However there are a number of characteristics that collectively and simultaneously act as drivers and constraints to technology adoption and acceptance. Nurse and Punnet [28] posit that these characteristics ultimately determine and influence the degree of technology diffusion or acceptance in that country. Figure 2 below depicts a number of characteristics that are unique, from one country to another that ultimately influences the rate of technology adoption and acceptance.

Figure 2 - Host Country Characteristics and Technology Acceptance

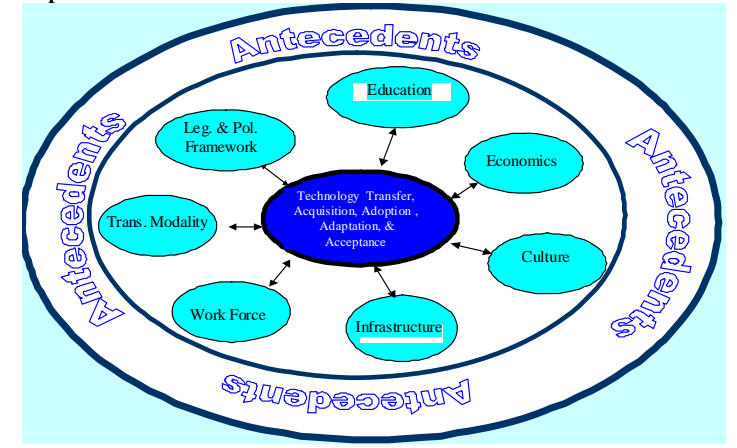




\section{RESEARCH QUESTIONS}

This research seeks to answer the following questions: 1) What relationship exists between Access to e-commerce readiness services and technology acceptance (Access dimension)?

2.) What relationship exists between Business Utilization of Internet Services and technology acceptance in Barbados? (Current Utilization dimension)?

\section{METHODOLOGY}

A listing of companies from the Barbados Industrial Development Corporation annual report, Barbados Manufacturers and Service Companies Directory [5] showed that there are approximately 500 companies operating in Barbados. Of these 500 companies, approximately 100 are providing IT products and or services. This constituted the sample population.

A survey instrument was completed by managers of IT companies operating in Barbados. These companies were grouped and the survey instrument was applied to: (a) IT companies that are exclusively owned and operated by Barbadians; (b) IT companies that are jointly owned and operated by Barbadians and foreigners; (c) IT companies that are owned and operated exclusively by foreigners in Barbados. From each company, supervisors and managers who participated in the study were asked to complete the questionnaire. The questionnaire was distributed to 97 IT companies in Barbados. As a follow-up, where possible, an e-mail was also sent to these companies. A total of 42 responses were returned within three weeks. Ten of the returns were unusable because the respondents had moved with no forwarding address, were no longer in business, and in some cases deceased. This yielded an overall response rate of 36.8 percent.

The data collection instrument was a composite threepart questionnaire, including: (a) selected questions derived from e-commerce readiness assessment guidelines [2][29][25], (b) the items from the TAM2 questionnaire [29] and (c) a set of demographic questions that sought to obtain an overall description of each respondent.

Reliability was determined using Cronbach's Alpha Coefficients. The reliability and measures of effectiveness that were utilized in the present study were demonstrated to be stable in a number of investigations performed by different research teams, and under diverse testing conditions. According to Nunnally [27], reliability estimates that are greater than .50 are sufficient for basic research. The results for this study ranged between .52 and .81 .

\section{RESULTS}

\section{Basic Infrastructure Relationship with E-Mail and Internet Technologies:}

Using Pearson's correlation, the data, suggest that there are strong relationships between a basic e-commerce infrastructure and e-mail or Internet usage. In addition, the data showed strong intra-relationships between TAM variables for each technology. With respect to Internet technology, there exists a strong relationship between Basic Infrastructure and Perceived Usefulness. See tables $1 \& 2$.

\section{Current Utilization Relationship with E-Mail and Internet Technologies}

Using Pearson's "one-Tail” correlation, the data suggest that there are strong relationships between an ecommerce current utilization and e-mail and Internet usage. There is also a strong relationship between ecommerce Current Utilization and Internet Perceived Usefulness; between Current Utilization and Internet Perceived Ease of Use; and between Current Utilization and Internet Job Relevance. In addition, the data showed strong intra-relationships between TAM variables for each technology. See tables 3 and 4 .

\section{Educational Levels Influence on Technology Acceptance}

ANOVA one-way analysis was used to examine this relationship. For respondents who perceive usefulness of e-Mail technology for e-Commerce activity, the likelihood that different levels of education is significant in their acceptance of that technology. For respondents who intend to use the internet for e-Commerce activity, there is a high probability that different levels of education are significant in their decision to accept that technology. It appeared that in general, as respondents progressed from "intent to use" to "voluntary" use, higher levels of education became less significant. See table 5 and 6.

\section{Hypotheses Testing}

$\mathrm{H} 1_{\mathrm{A}}$ : A viable e-commerce Basic Infrastructure will be positively correlated with technology acceptance of companies in Barbados.

Pearson's correlation test results revealed that there are both weak and strong relationships between e-Commerce basic infrastructure and e-Mail and Internet technology acceptance. There are also both weak and strong relationships with respect to TAM internal dimensions for both e-Mail and Internet applications. Therefore this hypothesis has been partially supported. Further studies are therefore necessary to determine the reasons for the 
simultaneous existence of both weak and strong correlations.

$\mathrm{H} 2_{\mathrm{A}}$ :Utilization of e-Mail and Internet technologies will be positively correlated with the level of technology acceptance of companies in Barbados.

Pearson's correlation test results revealed that there are both weak and strong relationships between e-Commerce current utilization for e-Mail and Internet technology acceptance. There are also both weak and strong relationships with respect to TAM internal dimensions for both e-Mail and Internet applications. Therefore this hypothesis has been partially supported. Similar to the results associated with Hypothesis \# 1, further studies are therefore necessary to determine the reasons for the simultaneous existence of both weak and strong correlations.

$\mathrm{H}_{\mathrm{A}}$ : There is a significant difference in the average TAM of companies in Barbados' based Work force educational levels.

Using one-way ANOVA test, the results suggest that, in general, there is no significant difference in average Barbadian workforce personnel, based on levels of education regarding e-mail and internet technologies for e-Commerce activities. Except for Internet "intent to use" dimension, (probability of 1.7 percent that levels of education are significant) all other dimension for both eMail and Internet technology acceptance, show that levels of education are either marginally significant or not significant at all; these probability values range from 5.2 percent to 88.9 percent. Therefore HЗa has been supported.

\section{DISCUSSION OF RESULTS}

Using a one-tail Pearson's Correlation to examine those relationships led to certain conclusions summarized below:

E-Mail Intra-Relationships: A strong relationship exists between Perceived Usefulness and Intent to Use; a strong relationship exists between Perceived Usefulness and Job Relevance; a strong relationship exists between Perceived Ease of Use and Job Relevance.

Internet Intra-Relationships: A strong relationship exists between Perceived Usefulness and Job Relevance. A strong relationship exists between Perceived Ease of Use and Job Relevance.

Internet and E-Mail Inter-Relationships: A strong relationship exists between Internet Perceived Usefulness and e-mail Job Relevance. A strong relationship exists between the Internet Perceived Ease of Use and e-mail Job Relevance.

Volume IX, No 1, 2008
Significance of Educational Levels: One-way ANOVA test show that levels of education has no significance relative to e-Mail or Internet technology acceptance. This study attempted to show that there exist strong relationships between selected e-commerce readiness dimensions and technology acceptance dimensions. Using e-mail and the Internet as the application technologies, and Multiple Correlation Analysis (MCA) methodology to examine those relationships, these relationships were partially supported. In addition, oneway ANOVA test shows that different levels of education do not influence technology acceptance relative to e-Commerce activities. Throughout this study, it was shown that when using e-mail and Internet technologies, there are strong relationships between ecommerce readiness and TAM dimensions. However, this result raises the question that is frequently asked: "Does technology acceptance comes before a community or organization is capable of creating and maintaining a particular infrastructure?” Arguably, in response to that question, certain levels of technology acceptance are necessary for a basic infrastructure. For example, a basic level of telecommunication infrastructure is always necessary. For it is on this infrastructure that ecommerce application and system are deployed. However, a prepared work force, appropriate education, appropriate government policies, and access to services, are necessary for sustaining and supporting a robust ecommerce readiness infrastructure and environment; thus an e-commerce readiness infrastructure is more complex than having basic technology acceptance.

So what then is technology acceptance, and how does it affect the development and sustainability of e-commerce activities? The argument may be made that technology acceptance is at the center of a credible infrastructure. Without the basic appropriate technology, which creates the foundation for an infrastructure, there can be no access to systems that facilitate e-commerce activities. Without appropriate technology and infrastructure, no credible electronic banking is possible [29]. Without appropriate technology and infrastructure, no secure e-commerce activities are possible [29]. Thus many factors influence the acceptance of technology that is appropriate for e-commerce activities [30][31][29][35][21][1][12].

This study explored the relationship between the acceptance and usage two specific IT applications (email and Internet), and selected components of ecommerce readiness. The assumption was made that a level of technology existed that supported the utilization of those IT applications. Since these two IT applications are the primary vehicles through which e-commerce activities are conducted, we sought to examine the relationship between the acceptance of these two applications and the respondents' use of them to undertake e-commerce activities. The results indicate 
that, for e-mail usage: (1) there is a strong and positive relationship between current utilization and perceived usefulness; (2) there is a strong positive relationship between Current Utilization and Job Relevance; (3) there is a strong and positive relationship between Perceived Usefulness and Intent to Use; (4) there is a strong and positive relationship between Perceived Usefulness and Job Relevance; there is a strong and positive relationship between Perceived Ease of Use and Job Relevance.

The results also show that, for Internet usage: (a) there is a strong and positive relationship between Current Utilization and Job Relevance; (b) there is a strong and positive relationship between Perceived Usefulness and Job Relevance; (c) there is a strong relationship between Perceived Ease of Use and Job Relevance.

\section{IMPLICATIONS FOR BUSINESS DEVELOPMENT}

The increasing importance and proliferation of information technologies, and end -user technology acceptance, for e-commerce activities, suggest that an infrastructure and access to that infrastructure are necessary for wide-spread e-commerce activities [30]. This proliferation has facilitated increased e-commerce activities and more technology acceptance in organizations and communities [31]. Thus there is an intricate relationship between a supportable and sustainable infrastructure, access to and utilization of that infrastructure, key IT applications, and the levels of e-commerce activities.

However many organizations, that are desirous of greater e-commerce activities, frequently experience many setbacks and frustrations that are associated with inadequate infrastructure, inadequate access, and a general lack of education in this particular area. In many cases, these organizations also have a general lack of knowledge in information technology, and inadequate hardware and software. There is often a general need to rely on outside resources and experience to offset their shortage or absence of technical support. Pavlou, [30] suggests that greater trust in the available e-commerce infrastructure will demand greater technology acceptance. Oxley and Yueng [29] argued that a supportable and sustainable infrastructure is necessary for increased e-commerce activities. Pavlou and Gefen [31] posit that an appropriate education is also essential for greater e-commerce activities. When take together, and an innate comprehensive knowledge in many areas associated with information technology become essential for sustaining and expanding e-commerce activities.
This study examined the relationship between the utilization of e-mail and Internet applications with ecommerce readiness components. Managers of organizations, who want, or plan to, purchase more IT applications for e-commerce activities, are able to take into consideration some of the issues that affect technology acceptance as it relates to e-commerce activities.

After discussing the initial findings of this study with some of Barbados' government and diplomatic personnel in the United States, it was suggested that copies of this study be made available to a number of ministries in Barbados. Some of these ministries included: (a) the Prime Minister of Barbados who is also the Minister of Finance; (b) the Ministry of Education; (c) and the Ministry of Economic Development. It was stated that these ministries represent the vanguard for e-commerce development in Barbados and that this research will become a resource that facilitate the decisions that will be made by policy makers.

\section{LIMITATIONS}

There are several limitations associated with this study. First, the data was collected using questionnaires that were mailed to selected managers of IT companies in Barbados.

Second, this study targeted IT organizations in Barbados, considering that these companies were more likely than others to use e-mail and the internet, and to have ecommerce capability and greater technology acceptance. It is the author's conviction that had all 500+ companies that are operating in Barbados were included in the study, there is the likelihood that the survey might have yielded different results.

Third, the study was confined to Barbados and no attempts should be made to apply the results to other Caribbean nations. Future studies may seek to replicate this study in other islands in the region.

\section{FUTURE WORK}

In future research studies, all registered companies operating in Barbados should be included. A study of the full range of companies will more likely yield more complete information relative to the relationship between e-commerce readiness and levels of technology acceptance in Barbados.

Other components of e-commerce readiness should be considered in future research. This study selected components that were considered basic relative to 
conducting e-commerce activities. However it is accepted that the other components may have equal influence on successful e-commerce activities. These components include: (a) Government Promotion, (b) Facilitating Activities, and (c) Positioning for Digital Economy (government policies, legal issues among others.

Future studies should also try to predict how ecommerce readiness may encourage greater levels of technology acceptance and how greater levels of technology acceptance predict increased levels of ecommerce activities. Specifically, these studies may be designed to examine the weight that each e-commerce readiness component may have on levels of technology acceptance and vise versa. Additional studies may also be developed to examine the relationship between technology acceptance and other host country antecedents, such as economics, government policies workforce preparedness, and so on. A key area of research may be that of exploring whether or not these host country dynamics are predictors for level of ecommerce activities.

Another area for future studies is in the area of more robust statistical analyses.

\section{REFERENCES}

1. Adams, D. A, Nelson, R.R, Todd, P.A: (1992 June) Perceived Usefulness, Ease of Use, and Usage of Information. MIS Quarterly; Minneapolis, pp. $227-247$.

2. Asia-Pacific Economic Corporation (APEC) Readiness Initiative (2000). E-commercereadiness Assessment Guide; www.wcommerce.gov/apec

3. Ajzen, I and Fishbein, M. (1975) Belief, Attitude, Intention and Behavior: An Introduction to Theory and Research, Reading, Mass: Addison-Wesley.

4. Ajzen, I. and Fishbein, M.(1980), Understanding Attitudes and Predicting Social Behavior,Englewood Cliffs, NJ: Prentice-Hall,Inc.

5. Barbados Manufacturers and Service Companies Directory (2000). Barbados Investment and Development Corporation. Bridgetown, Barbados.

6. Boswell, T.D., and Conway, D. , (1992). The Caribbean Islands - Endless GeographicalDiversity, Rutgers University Press, New Brunswick, N.J.

7. Chau, P.Y.K (Fall 1996) An Empirical Assessment of a Technology Acceptance Model. Journal of Management Information System, Armonk.
8. Collins, M. R. (1994). An investigation into the impact of guidance within a computer- based decision support system environment. (Doctoral Dissertation, University of Arkansas, 1994). Dissertation Abstracts International, 55(12), 5424.

9. Davis, F.D. (1986)."A Technology Acceptance Model for Empirically Testing New End-User Information System: Theory and Results", Doctoral Dissertation, Sloan School of Management, Massachusetts Institute of Technology.

10.Davis, F.D. (1989 - September) Perceived Usefulness, Perceived Ease of Use, and User Acceptance of Information Technology. MIS Quarterly, pp. 319 - 340.

11. Davis, F.D. (1993) User Acceptance of Information Technology: System Characteristics, User Perceptions and Behavioral Impacts. International Journal of Man-Machine Studies, 38.

12. Davis, F.D., Bagozzi,. R.P, and Warshaw, P.R. ((1989) User Acceptance of Computer Technology: A Comparison of Two Theoretical Models. Management Science, 35(8).

13. Davis, F.D. and Venkatesh, V. (1995). Measuring User Acceptance of Emerging Information Technologies: An Assessment of Possible Method Biases. Proceedings of the Twenty-Eighth Annual Hawaii International Conference on Systems Sciences, January, Wailea, Maui, Hawaii, Vol 4, pp729-736.

14. Dillion, T. W., McDowell, D., Salimian, F., and Conklin, D. (1996). Acceptance of Bedside Computer Technology [On-Line]. Available: http://hsb.baylor.edu/ramsower/ais.ac.96/papers/dill on.htm

15. Ferguson, C. (1997). The effects of microcomputers on the work of professional accountants. Accounting and Finance, 37, pp. 41-67.

16. Fenech, T. 1997, 'Using perceived ease of use and perceived usefulness to predict acceptance of the World Wide Web', Computer Networks and ISDN Systems, 30, pp. 629-630.

17. Gefen, D. and Straub, D. W. (1997) "Gender Differences in Perception and Adoption of E-Mail: An Extension to the Technology Acceptance Model," MIS Quarterly, 21(4), pp. 389-400. 
18. Heijden, Han van der: (2000 - July) Factors influencing the Usage of Websites: The Case of a Generic Portal in the Netherlands. Vrije University Amsterdam, Netherland.

19. Hubona, G.S. and Kennick, E (1996) The Impact of External Variables on Information Technology Usage Behavior. Proceedings of the 29th Annual Hawaii International Conference of System Sciences.

20. Hubona, G.S. and Geitz S. (1997) External Variables, Beliefs, Attitudes and Information Technology Usage Behavior. Proceedings of the 30th Annual Hawaii International Conference of System Sciences.

21. Igbaria. M., Zinatelli. N., Cragg. P, Cavaye. AL.M. (1997 - September) Personal Computing Acceptance Factors in Small Firms: A Structural Equation Model. MIS Quarterly, pp.279 - 302.

22. Igbaria, M. and Tan, M. (1997) The Consequences of Information Technology Acceptance on Subsequent Individual Performance. Information and Management, 32.

23. Jackson, C.M, Chow, S., and Leitch, R.A. (1997). Toward an Understanding of the Behavioral Intention to Use an Information System. Decision Sciences; Atlanta; 28(2).

24. Kim, I. (1996). The effects of individual, managerial, organizational, and environmental factors on the adoption of object orientation in u.s. organizations: An empirical test of the technology acceptance model (management information systems), (Doctoral Dissertation, The University of Nebraska,). Dissertation Abstracts International, 57(09), 4027.

25. McConnell, B. and Docktor, R. (2000 - August) Risk E-Business: Seizing the Opportunity of Global EReadiness; McConnell International LLC.

26. Morris, M.G. and Dillon, A. (July/August 1997) How User Perceptions Influence Software Use. IEEE Software.

27. Nunnally, J. C. (1967). Psychometric theory. New York: McGraw-Hill.

28. Nurse, L. and Punnet, B.J.: (August 2001) Management Research on the English Speaking Caribbean: Towards a Research Agenda (Academy of Management Annual Meeting), Washington, DC.
29. Oxley, J.E and Yeung, B (2001) E-commerce readiness: Institutional Environment and International Competitiveness; Journal of International Business Studies, 32(4), pp. 705 - 723.

30. Pavlou, P.A. (2002) Institute-Based Trust in Interorganizational Exchange Relationship: The Role of Online B2B Marketplace on Trust Formation; Journal of Strategic Information Systems, Special Issue " "Trust in the Digital Economy’, 11, 4 (forthcoming).

31. Pavlou, P.A and Gefen, D. (2002) Building Effective Online Marketplace With Institution-Based Trust; Proceeding of the 2002 International Conference on Information System, Barcelona, Spain.

32. Satzinger, J. and Olfman, L. (1995) Computer support for group work: Perceptions of the usefulness of support scenarios and end-user tools, Journal of Management Information Systems, 11(4), pp.115-148.

33. Steer, D., Turner, P., Spencer, S. and Godfrey, B (2001) Issues Adapting The Technology Acceptance Model (TAM) To Investigate Non-Workplace Usage Behavior on the World-Wide-Web, University of Tasmania, Australia.

34. Subramanian, G. H., and Khosrowpour, M A (1996) "Comparison of Voice Mail and Information Retrieval Systems on Technology Acceptance and Information Characteristics", Proceedings of the Association of Information Systems Conference, Phoenix, AZ, pp. 241-243.

35. Szajna, B. 1994, 'How much is information systems research addressing key practitioner concerns?', Data Base, 25(2), pp. 49-59.

36. Szajna, B. (1996 - January) Empirical Evaluation of the Revised Technology Acceptance Model. Management Science, 42(1).

37. Taylor, S., and Todd, P. (1995, December). Assessing IT Usage: The Role of Prior Experience. MIS Quarterly, 19(4), pp. 561-570.

38. Trotter, D. L. (1993). The Acceptance and Effectiveness of Hypertext Systems in Legal Education: An Experimental Evaluation (Doctoral Dissertation, University of South Carolina, 1993). Dissertation Abstracts International, 54(7). 
39. Venkatesh, V. and Davis, F.D. (2000 February), A Theoretical Extention of the Technology Acceptance Model: Four Longitudinal Field Studies, Management Science, 46(2), 186 - 204.

40. Wynekopp, J.L. (1996). Office Computer Systems in Healthcare: Use and Assessment. Journal of End User Computing, Vol 8. Pp. $22-30$

Correlation

\begin{tabular}{|c|c|c|c|c|c|c|c|}
\hline & & BINF & EINT & EPU & EPEOU & EJR & EVOL \\
\hline \multirow[t]{3}{*}{ BINF } & Pearson Correlatio & 1.000 & .280 & $.345^{*}$ & .094 & .161 & -.251 \\
\hline & Sig. (1-tailed) & & .067 & .031 & .311 & 197 & .090 \\
\hline & $\mathrm{N}$ & 30 & 30 & 30 & 30 & 30 & 30 \\
\hline \multirow[t]{3}{*}{ EINT } & Pearson Correlatid & .280 & 1.000 & $.519^{\star}$ & .119 & .146 & -.223 \\
\hline & Sig. (1-tailed) & .067 & & .002 & .265 & .220 & .118 \\
\hline & $\mathrm{N}$ & 30 & 30 & 30 & 30 & 30 & 30 \\
\hline \multirow[t]{3}{*}{ EPU } & Pearson Correlatid & $.345^{*}$ & $.519 * *$ & 1.000 & .302 & $.468^{\star}$ & -.011 \\
\hline & Sig. (1-tailed) & .031 & .002 & . & .052 & .005 & .478 \\
\hline & $\mathrm{N}$ & 30 & 30 & 30 & 30 & 30 & 30 \\
\hline \multirow[t]{3}{*}{ EPEOU } & Pearson Correlatio & .094 & .119 & .302 & 1.000 & $.374^{*}$ & -.051 \\
\hline & Sig. (1-tailed) & 311 & .265 & .052 & . & .021 & .394 \\
\hline & $\mathrm{N}$ & 30 & 30 & 30 & 30 & 30 & 30 \\
\hline \multirow[t]{3}{*}{ EJR } & Pearson Correlatid & .161 & .146 & $.468^{\star}$ & $.374^{*}$ & 1.000 & -.088 \\
\hline & Sig. (1-tailed) & 197 & 220 & .005 & .021 & & 322 \\
\hline & $\mathrm{N}$ & 30 & 30 & 30 & 30 & 30 & 30 \\
\hline \multirow[t]{3}{*}{$\overline{\mathrm{EVOL}}$} & Pearson Correlatid & -.251 & -.223 & -.011 & -.051 & -.088 & 1.000 \\
\hline & Sig. (1-tailed) & .090 & .118 & .478 & .394 & .322 & . \\
\hline & $\mathrm{N}$ & 30 & 30 & 30 & 30 & 30 & 30 \\
\hline
\end{tabular}

*. Correlation is significant at the 0.05 level (1-tailed).

**. Correlation is significant at the 0.01 level (1-tailed).

Table 3 - Correlation Current Utilization and e-Mail Technology

\begin{tabular}{|c|c|c|c|c|c|c|c|}
\hline \multicolumn{8}{|c|}{ Correlations } \\
\hline & & UTIL & EINT & EPU & EPEOU & EJR & EVOL \\
\hline \multirow[t]{3}{*}{ UTIL } & Pearson Correlation & 1.000 & .282 & $.501^{*}$ & $.337^{*}$ & $.557 *$ & -.153 \\
\hline & Sig. (1-tailed) & & .066 & .002 & .034 & .001 & .209 \\
\hline & $\mathrm{N}$ & 30 & 30 & 30 & 30 & 30 & 30 \\
\hline \multirow[t]{3}{*}{ EINT } & Pearson Correlation & .282 & 1.000 & $.519^{*}$ & .119 & .146 & -.223 \\
\hline & Sig. (1-tailed) & .066 & & .002 & .265 & .220 & .118 \\
\hline & $\mathrm{N}$ & 30 & 30 & 30 & 30 & 30 & 30 \\
\hline \multirow[t]{3}{*}{ EPU } & Pearson Correlation & $.501 * 4$ & $.519 *$ & 1.000 & .302 & $.468^{* 1}$ & -.011 \\
\hline & Sig. (1-tailed) & .002 & .002 & . & .052 & .005 & .478 \\
\hline & $\mathrm{N}$ & 30 & 30 & 30 & 30 & 30 & 30 \\
\hline \multirow[t]{3}{*}{ EPEOU } & Pearson Correlation & $.337^{\star}$ & .119 & .302 & 1.000 & $.374^{*}$ & -.051 \\
\hline & Sig. (1-tailed) & .034 & .265 & .052 & . & .021 & .394 \\
\hline & $\mathrm{N}$ & 30 & 30 & 30 & 30 & 30 & 30 \\
\hline \multirow[t]{3}{*}{ EJR } & Pearson Correlation & $.557 *$ & .146 & $.468 *$ & $.374^{*}$ & 1.000 & -.088 \\
\hline & Sig. (1-tailed) & .001 & .220 & .005 & .021 & & .322 \\
\hline & $\mathrm{N}$ & 30 & 30 & 30 & 30 & 30 & 30 \\
\hline \multirow[t]{3}{*}{ EVOL } & Pearson Correlation & -.153 & -.223 & -.011 & -.051 & -.088 & 1.000 \\
\hline & Sig. (1-tailed) & .209 & .118 & .478 & .394 & .322 & \\
\hline & $\mathrm{N}$ & 30 & 30 & 30 & 30 & 30 & 30 \\
\hline
\end{tabular}

Tables \& Figures

Table 1 - Correlation Between Basic Infrastructure and e-Mail

Table 2- Correlation Between Basic Infrastructure and Internet

\begin{tabular}{|c|c|c|c|c|c|c|c|}
\hline \multicolumn{8}{|c|}{ ations } \\
\hline & & BINF & IINT & IPU & IPEOU & $\mathrm{IJR}$ & IVOL \\
\hline \multirow[t]{3}{*}{ BINF } & Pearson Correlation & 1.000 & .068 & $.353 *$ & .211 & .266 & -.225 \\
\hline & Sig. (1-tailed) & & .360 & .028 & .131 & .077 & .116 \\
\hline & $\mathrm{N}$ & 30 & 30 & 30 & 30 & 30 & 30 \\
\hline \multirow[t]{3}{*}{ IINT } & Pearson Correlation & .068 & 1.000 & -.077 & .066 & -.212 & -.127 \\
\hline & Sig. (1-tailed) & .360 & & .344 & .365 & .131 & .252 \\
\hline & $\mathrm{N}$ & 30 & 30 & 30 & 30 & 30 & 30 \\
\hline \multirow[t]{3}{*}{ IPU } & Pearson Correlation & $.353 *$ & -.077 & 1.000 & .238 & $.443 * *$ & .047 \\
\hline & Sig. (1-tailed) & .028 & .344 & & .102 & .007 & .402 \\
\hline & $\mathrm{N}$ & 30 & 30 & 30 & 30 & 30 & 30 \\
\hline \multirow[t]{3}{*}{ IPEOU } & Pearson Correlation & .211 & .066 & .238 & 1.000 & .691 * & -.051 \\
\hline & Sig. (1-tailed) & .131 & .365 & .102 & . & .000 & .394 \\
\hline & $\mathrm{N}$ & 30 & 30 & 30 & 30 & 30 & 30 \\
\hline \multirow[t]{3}{*}{ IJR } & Pearson Correlation & .266 & -.212 & .443 ** & .691 ** & 1.000 & -.015 \\
\hline & Sig. (1-tailed) & .077 & .131 & .007 & .000 & 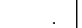 & .469 \\
\hline & $\mathrm{N}$ & 30 & 30 & 30 & 30 & 30 & 30 \\
\hline \multirow[t]{3}{*}{ IVOL } & Pearson Correlation & -.225 & -.127 & .047 & -.051 & -.015 & 1.000 \\
\hline & Sig. (1-tailed) & .116 & .252 & .402 & .394 & .469 & . \\
\hline & $\mathrm{N}$ & 30 & 30 & 30 & 30 & 30 & 30 \\
\hline
\end{tabular}

Table 4 - Correlation Between Current Utilization and Internet Technology

\begin{tabular}{|c|c|c|c|c|c|c|c|}
\hline \multicolumn{8}{|c|}{ Correlations } \\
\hline & & UTIL & IINT & IPU & IPEOU & IJR & IVOL \\
\hline \multirow[t]{3}{*}{ UTIL } & Pearson Correlation & 1.000 & .137 & $.334^{*}$ & $.325^{*}$ & $.528^{*}$ & -.141 \\
\hline & Sig. (1-tailed) & & .235 & .035 & .040 & .001 & .228 \\
\hline & $\mathrm{N}$ & 30 & 30 & 30 & 30 & 30 & 30 \\
\hline \multirow[t]{3}{*}{ IINT } & Pearson Correlation & .137 & 1.000 & -.077 & .066 & -.212 & -.127 \\
\hline & Sig. (1-tailed) & .235 & & .344 & .365 & .131 & .252 \\
\hline & $\mathrm{N}$ & 30 & 30 & 30 & 30 & 30 & 30 \\
\hline \multirow[t]{3}{*}{ IPU } & Pearson Correlation & $.334^{\star}$ & -.077 & 1.000 & .238 & $.443^{\star \star *}$ & .047 \\
\hline & Sig. (1-tailed) & .035 & .344 & & .102 & .007 & .402 \\
\hline & $\mathrm{N}$ & 30 & 30 & 30 & 30 & 30 & 30 \\
\hline \multirow[t]{3}{*}{ IPEOU } & Pearson Correlation & $.325 *$ & .066 & .238 & 1.000 & $.691 *$ & -.051 \\
\hline & Sig. (1-tailed) & .040 & .365 & .102 & & .000 & .394 \\
\hline & $\mathrm{N}$ & 30 & 30 & 30 & 30 & 30 & 30 \\
\hline \multirow[t]{3}{*}{ IJR } & Pearson Correlation & $.528 * *$ & -.212 & $.443^{*}$ & .691 채 & 1.000 & -.015 \\
\hline & Sig. (1-tailed) & .001 & .131 & .007 & .000 & & .469 \\
\hline & $\mathrm{N}$ & 30 & 30 & 30 & 30 & 30 & 30 \\
\hline \multirow[t]{3}{*}{ IVOL } & Pearson Correlation & $\begin{array}{l}.141 \\
\end{array}$ & -.127 & .047 & -.051 & -.015 & 1.000 \\
\hline & Sig. (1-tailed) & .228 & .252 & .402 & .394 & .469 & . \\
\hline & $\mathrm{N}$ & 30 & 30 & 30 & 30 & 30 & 30 \\
\hline
\end{tabular}


Table 5 - Educational Level to e-Mail Acceptance for e-Commerce Activities

\begin{tabular}{|c|c|c|c|c|c|c|c|}
\hline EIN & Between & Sum & & & & & \\
\hline \multirow[b]{3}{*}{ EP } & $\begin{array}{l}\text { Within } \\
\end{array}$ & squgerefo & dif 26 & \multicolumn{2}{|c|}{ Thean $\quad .356$} & \multirow[t]{2}{*}{$F$} & \multirow[t]{2}{*}{ Sig. } \\
\hline & Total & 11.80 & 29 & & & & \\
\hline & Between & 2.640 & 3 & & .880 & 2.942 & .052 \\
\hline \multirow[b]{3}{*}{ EPEO } & Within & 7.777 & 26 & \multirow{2}{*}{\multicolumn{2}{|c|}{.299}} & \multirow[b]{3}{*}{1.045} & \multirow[b]{3}{*}{.389} \\
\hline & Total & 10.41 & 29 & & & & \\
\hline & Between & 1.589 & 3 & & .530 & & \\
\hline \multirow[b]{3}{*}{ EJ } & Within & 13.18 & 26 & \multirow{2}{*}{\multicolumn{2}{|c|}{.507}} & \multirow[b]{3}{*}{1.026} & \multirow[b]{3}{*}{.397} \\
\hline & Total & 14.76 & 29 & & & & \\
\hline & Between & 1.319 & 3 & & .440 & & \\
\hline \multirow{5}{*}{ EVO } & Within & 11.14 & 26 & \multirow{2}{*}{\multicolumn{2}{|c|}{.429}} & \multirow[b]{3}{*}{.363} & \multirow[b]{3}{*}{.780} \\
\hline & Total & 12.46 & 29 & & & & \\
\hline & Between & 2.751 & 3 & & .917 & & \\
\hline & Within & 65.61 & 26 & \multirow{2}{*}{\multicolumn{2}{|c|}{2.524}} & & \\
\hline & Total & 68.37 & 29 & & & & \\
\hline
\end{tabular}

Table 6 - Educational Level to Internet Acceptance for e-Commerce activities

\begin{tabular}{|ll|r|r|r|r|r|}
\hline & \multicolumn{1}{|c|}{$\begin{array}{c}\text { Sum of } \\
\text { Squares }\end{array}$} & df & Mean Square & \multicolumn{1}{c|}{ F } & Sig. \\
\hline IINT & Between Groups & 3.315 & 3 & 1.105 & 4.073 & .017 \\
& Within Groups & 7.052 & 26 & .271 & & \\
& Total & 10.367 & 29 & & & \\
\hline IPU & Between Groups & 1.164 & 3 & .388 & 1.422 & .259 \\
& Within Groups & 7.096 & 26 & .273 & & \\
& Total & 8.260 & 29 & & & \\
\hline IPEOU & Between Groups & 1.296 & 3 & .432 & .618 & .610 \\
& Within Groups & 18.171 & 26 & .699 & & \\
& Total & 19.467 & 29 & & & \\
\hline IJR & Between Groups & .897 & 3 & .299 & .798 & .506 \\
& Within Groups & 9.746 & 26 & .375 & & \\
& Total & 10.644 & 29 & & & \\
\hline IVOL & Between Groups & 1.435 & 3 & .478 & .210 & .889 \\
& Within Groups & 59.255 & 26 & 2.279 & & \\
& Total & 60.690 & 29 & & & \\
\hline
\end{tabular}

